\title{
Incidence of Fungi in Water Springs of Samahni Valley, District Bhimber, Azad Kashmir, Pakistan
}

\author{
Tanveer Hussain \\ Department of Botany, University of Azad Jammu and Kashmir, Muzaffarabad, Pakistan
}

Tel: 92-582-296-0431

Muhammad Ishtiaq Ch (Corresponding author)

Department of Botany, Mirpur University of Science \& Technology (MUST)

Bhimber Campus, Azad Kashmir, Pakistan

Tel: 92-582-796-0235Ｅ-mail: drishtiaqajk@gmail.com; drishtiaq@must.edu.pk

\author{
Altaf Hussain \\ Department of Botany, Mirpur University of Science \& Technology (MUST) \\ Bhimber Campus, Azad Kashmir, Pakistan
}

Tel: 92-582-796-0235

Tariq Mehmood

Department of Botany, University of Azad Jammu and Kashmir, Muzaffarabad, Pakistan

Tel: 92-582-296-0431

Kishwar Sultana

Department of Plant Pathology, Arid Agricultural University, Rawalpindi, Pakistan

Muhammad Ashraf

University College of Agriculture, Rawalakot, Azad Kashmir, Pakistan

Tel: 92-582-296-0431 E-mail: chashraf_horti@hotmail.com

\begin{abstract}
Fungi have great impacts on socio-economic conditions and health of human beings. In current research, incidence of mycoflora associated with different water springs of Samahni Valley (SV), district Bhimber, Azad Kashmir was screened by using Plating and Baiting Techniques. The $\mathrm{pH}$ value of water samples ranged from 5.5 to 7.5 . The minimum and maximum temperature of sampled springs was between $18^{\circ} \mathrm{C}-36^{\circ} \mathrm{C}$. Total 33 fungal specimens belonging to 21 different species were isolated from different analyzed samples by employing two approaches. In Baiting Technique (BT) 13 species and in Direct Plate Method (DPM) 8 species were isolated, respectively. Highest number of mycoflora was determined by BT, followed by DPM. Aspergillus sp. was dominant species followed by Cephalosporium sp. and Botrytis sp. found in drinking water of springs. The highest number of species was found in Parshala sample (6 spp) which proves that place has favorable conditions for flourishing of fungi. The present study depicts that various springs of SV have different number of mycoflora depending on soil type, temperature, altitude and neighboring flora. Furthermore, ethnobotanical study of the area indicates that these pathogenic species present in spring water cause many diseases in plants, animals and human beings, hence hampering health and economic status of inhabitants. It is recommend that precautionary and practical measures should be formulated and implemented before using water of these springs for drinking or other agriculture purposes.
\end{abstract}


Keywords: Spring water Fungi, Samahni, Pathogenic, Azad Kashmir, Water pollution, Direct Plate Method, Baiting Technique

\section{Introduction}

Water is the most common essential and inevitable subsistence for life existence without which life would be impossible (Shiklomanov, 2000). Although human life can exist for many days without food but not without water (Tebbutt, 1998). A feature of most natural water is that they contain a wide variety of microorganisms and other organic and inorganic chemicals which are related to water quality and other environmental factors. These contaminants have harmful effects on lives of human and other organisms when their concentration exceeds the recommended level (Anonymous, 1975). Due to advances in science, now there is pretty enough literature on significance of fungi present in drinking water (Hageskal et al., 2007). Different fungi growing in drinking water resources are involved in modifying tastes and odours of water. It is known that certain organic compounds i.e. lipid, ergo sterol enhance the growth of fungi in water (Kelly et al., 2003).

In freshwater more than 600 fungi species proliferate and many of those cause health and economic losses for human beings (Wong et al., 1998; Tebbutt, 1998). In past study Goncalves reportd that Penicillium, Acremonium, Aspergillus, Mucor, Cladosporium sp., Rhizopus stolonifer, Chaetomium spp., Alternaria spp., were common in tap water (Goncalves et al., 2006). Previous research cascades that many species of genus Aspergillus are found in water and are causative agents of kidney and liver disorders, allergy, burns, otitis media and increase risk of invasive infections (De Hoog et al., 2000; Denning, 1998). Penicillium sp. is frequently found in fresh water and its implication in allergy, asthma or other respiratory problems has been cited in many previous studies (Schwab \& Straus, 2004). In another research, Cooley in 1998 has reported that many health problems are associated with presence of Penicillium sp. in fresh water. In 2008, Sameera has conducted quantitative analysis of mycoflora in drinking water and juices of Karachi and detailed analysis has been presented.

Pakistan located in south Asia, has landlocked soil with mountainous terrains having variable climatic habitats. Samahni Valley is one the Tehsil of district Bhimber, State of Azad Kashmir, Pakistan. Geographically SV is located between $33.05^{\circ}$ latitude and $74.82^{\circ}$ longitude. It covers ca. $1270 \mathrm{~km}^{2}$ and has 12 towns viz. Jandichontara, Dab, Bandala, Samahni, Chowki, Bindi, Jandala, Poona, Chaai, Baroh, Haripoor and Jajooha. It has north facing and south facing high mountains, with 1080-18975 ft altitude and variable topography (Ishtiaq et al., 2006, 2007). As springs are main source of drinking water in mountainous areas of Samahni Valley (SV), in Azad Kashmir, hence this research was carried out to analyze the mycoflora present in these natural resources of water and their subsequent effects on local communities.

\section{Materials and Methods}

Thirty samples were collected from eight different springs of Samahni Valley viz., Nihala (3), Kass (3), Parshala (4), Chitti Bawali (4), Bandala (5), Kho Pani (4), Tatali (3), Hill (4). Small amount of water was taken in beaker to record the $\mathrm{pH}$ of water of sample by using $\mathrm{pH}$ meter following protocol of Brady (1990).

Mycoflora was detected by Direct Plating Method (DPM), where one ml aliquot from each water sample was pipetted in 24 sterilized Petri plates (PPs) which already contained semi-solid sterilized water agar (WA) and streptomycin. It was mixed thoroughly and left to solidify for an appropriate time. Out of 24 cultures half were incubated at room temperature $\left(25 \pm 2^{\circ} \mathrm{C}\right)$ and others at $10 \pm 2^{\circ} \mathrm{C}$. After incubation period, fungi growing on PPs were examined at $10 \mathrm{X} \mathrm{OM}$ and fungal colonies were isolated and identified (Warcup, 1950).

In Baiting Technique (BT), water samples were collected in sterilized flasks and 40 hemp seeds were added to each flask. The flasks were kept in dark for 24 hours at room temperature $\left(25^{\circ} \mathrm{C}\right)$. These flasks were observed after 24 hours. The colonized seeds were transferred to sterilized PPs containing $20 \mathrm{ml}$ sterilized mixture of distilled water and tap water (1:1) equally with 2000 unitL $^{-1}$ of antibiotic Streptomycin to suppress bacterial growth. Ten seeds were placed in each Petri plate (PP). Thus 32 PPs were obtained from eight samples. 16 PPs containing colonized hemp seeds were incubated at $19^{\circ} \mathrm{C}$ and remaining incubated at room temperature $\left(25^{\circ} \mathrm{C}-30^{\circ} \mathrm{C}\right)$. The seeds were examined at 10X OM at weekly intervals for the study of fungal growth. The fungi were isolated and identified from these primary cultures. The rest of the fungi were identified after transference to pure culture in a PDA medium. Fungi were identified using mycological literature (Barnett, 1960; Domsch et al., 1980; Nelson et al., 1983; Raper et al., 1965).

\section{Results and Discussion}

The $\mathrm{pH}$ of analyzed water samples ranged from 5.5 to 7.5 and average Temp. of sampled water was between 18-31 ${ }^{\circ} \mathrm{C}$ (Table 4). In DPM, depicted density of sixteen which belonged to eight different fungal species viz., Aspergillus sp., Asteromyces sp., Botrytis sp., Cephalosporium sp., Monocellium sp., Penecillium sp., Sepedonium sp. and 
Tritirachium dependens were isolated from different spring's water samples. Among various localities, Parshala showed highest occurrence with 6 species while Tatali and Chitti bowali showed second ranking with incidence of three in each by DPM(Table1, Fig 3 6). The less occurrences of fungi in Parshala by BT is question for future research, which is being explored in our laboratory. Among these; three species viz., Aspergillus sp., Botrytis sp. and Penicillium sp. are human pathogens (De Hoog et al., 2000; Denning, 1998).

While by BT, 13 different fungal species viz., Aphanomyces keratinophilous, Asteromyces sp., Aspergillus sp., Brevilegnia sp., Botrytis sp., Cephalosporium sp., Chloridium sp., Curvularia sp., Cladosporium cladosporioides, Monocellium sp., Dreschleria havaiensis, Verticillium sp. and Verticillium terrestre were isolated from spring's water (Table 2, Fig 3 6). Out of these; 4 species viz., Aphanomyces keratinophilous, Aspergillus sp., Botrytis sp. and Curvularia sp. are various diseases in human beings (Goncalves et al., 2006; Schwab \& Straus, 2004).

As the main objective of the study was to determine the $\mathrm{pH}$ value, mycoflora and human pathogenic species associated with drinking water of the study area. The $\mathrm{pH}$ of samples analyzed was mostly acidic. Maximum number of species (6 No) were recorded in sample Parshala which has pH 6.1 and Temp $31^{\circ} \mathrm{C}$ (Table 4, Fig. 2). May be this is due to optimum Temp and $\mathrm{pH}$ or some other edapho-climatic factors which make it favorable for maximum fungal growth, but hitherto it needs more detailed future research to unravel this plethora. In other samples, various numbers of pathogenic species were found in variable density in the area (Fig. 2). Analyzed samples confirmed the mycoflora contamination in the drinking water and it is an important contributor to the transmission of wide variety of fungal disease to the water consumers of the area (Schwab \& Straus, 2004). In the present study, 21 fungal species were isolated (Table 3) and among these genus Penicillium was represented by highest density with 5 species, followed by genus Cephalosporium with four species. By ethnomycological survey and literature comparison it was known that 6 species viz., Aspergillus sp., Aphanomyces sp., Botrytis sp., Fusarium sp., Curvularia sp. and Penicillium sp. were pathogenic for human beings (Schwab \& Straus, 2004). Several of these species may be allergenic or cause infections to human beings (Wong et al., 1998; Tebbutt, 1998). The genus Aspergillus was found to be particularly widespread in the water samples as shown in Table 3 (Goncalves et al., 2006). We found that spring water containing Penicillium sp. caused allergy, asthma or other respiratory problems in the inhabitants of Samahni valley and same kind of findings are also mentioned in the past studies (Schwab \& Straus, 2004). Aphanomyces invadans caused skin ulcers and ethnobotanical study showed that the peoples who were living around the vicinity of selected springs, suffered in skin infections (Kiryu et al., 2003). Curvularia sp. produced skin infection and allergy in human beings. Our study also indicated that the peoples who were drinking water of the springs which contained Curvularia sp., suffered in skin infections (Safdar A., 2003). The information on the water mycoflora of Samahni valley is scanty and needs detailed hygienically examination of different springs. The local communities are advised to take precautionary measures during using mountainous spring water until proper analytical of those spring water is conducted and intimated to the public masses. The sources of water which have shown positive signal for pathogenic mycoflora in the current research should be avoided to be used as drinking water for man as well as for livestock. Attention should be taken in using fungal polluted water for irrigation purposes that may cause damage not only to crops and wild flora but also has injurious effects on domestic animals

Hence, here are some preliminary suggestions to use precautionary and biotechnical measures describing how to use fugal contaminated water of the mountainous springs. Peoples should follow the recommended suggestions:

1. Community awareness should be created by individual counseling as well as group discussions in different public forums.

2. Filter the water before use through micro-porous cotton cloth that can remove spore of fungi.

3. Mobilize the Government institutes to install filtration plants.

4. Launch NGOs based programs for establishment of filtration plants.

5. Motivate and teach local community to use boiled water which can hinder the diseases causing severity of fungal spores.

\section{Concluding Perspectives}

This research analysis predicts that different springs of SV are contaminated with variable number of fungi and many of them are pathogenic for human beings. This is also depicted that DPM produces more exhaustive and comprehensive results than BT. This study will be informative for mycologists, pathologists, medical specialists, pharmaceutists and more pertinent to layman that is directly interacting with environment of SV. Future detailed chemical, biological and other hygienic experimental researches will be beneficial for study of mycoflora as well as for better health and economy of the area. 


\section{References}

Anonymous. (1975). Standard methods for the examination of water and waste water, 14th ed., APHA-AWWA-WPCF. pp. 308-309.

Barnett, H.L. (1960). Illustrated Genera of Fungi Imperfecti. 2nd ed, Minneapolis: Burgess Publishing Company, pp. 225.

Brady, N.C. (1990). The Nature and Properties of soils. 10th ed, ISBN 0-13-852444-0. Macmillan pub, Company. New York pp. 881.

Cooley, J.D., W.C. Wong, C.A. Jumper and D.C. Straus. (1998). Correlation between the prevalence of certain fungi and sick building syndrome. Occup. Enviro. Med., 55: 579-584.

De Hoog, G.S., J. Guarru, J. Gene and M.J. Figueras. (2000). Atlas of Clinical fungi. Centraalbureau voor Schimmel cultures, Mycopathologia, Utrecht, The Netherlands. pp. 159-160.

Denning, D.W. (1998). Invasive aspergillosis, Clin. Infect. Dis., 26: 781-805.

Domsch, K.H., W. Gams and T.H. Anderson. (1980). Compendium of soil Fungi. Vol. I, Academic Press (London). Ltd., 24-28 Oval Road. London. NWI. pp. 859.

Gonçalves, A.B., R. Russell, M. Paterson and N. Lima. (2006). Surveys and significance of filamentous fungi from tap water. International journal of Hygiene and Environmental Health, 209(3): 257-264.

Green, B.J., Mitakakis, T.Z. and Tovey, E.R. (2003). Journal of Allergy and Clinical Immunology, Vol. 111(2):285-289.

Hageskal, G., P. Gaustad, B.T. Heier and I. Skaar. (2007). Occurrence of moulds in drinking water. Journal of Applied Microbiology, 102(3): 774-780.

Kelly J., G. Kinsey, R. Paterson, D. Brayford, R. Pitchers, R. Rossmore and H. Rossmore. (2003). Identification and control of fungi in distribution systems. Awwa Research Foundation and American water works Association, Denver. pp. 137.

Muhammad Ishtiaq, M. A. Khan and Wajahat Hanif. (2006). An Ethnomedicinal Inventory of Plants Used for Family Planning and Sex Diseases Treatment in Samahni Valley, (A. K. ) Pakistan. Pak. J. Biol. Sci., 9 (14): 2546-2555.

Muhammad Ishtiaq, Wajahat Hanif, M. A. Khan, M. Ashraf and Ansar M. Butt. (2007). An Ethnomedicinal Survey and Documentation of Important Medicinal Folklore Food Phytonims of Flora of Samahni Valley, (Azad Kashmir) Pakistan. Pak. J. Biol. Sci., 10 (13): 2241-2256.

Nelson, P.E., T.A. Toussoun and W.F.O. Marasas. (1983). Fusarium species, an Illustrated Manual of Identification. The University Press, University Park, Pennsylvania. pp. 203.

Raper, K.B., D.I. Fennell and P.K.C. Austwick. (1965). The genus Aspergillus. The Williams and Wilkins Company, Baltimore, pp. 686.

Sameera N., S.Dawar, M. Tariq and M.J. Zaki. (2008). Quantitative estimation of mycoflora in drinking water and fruit juices of Karachi. Pak. J. Bot., 40(3): 1263-1268.

Schwab, C.J. and D.C. Straus. (2004). The roles of Penicillium \& Aspergillus in sick buildings syndrome. Adv. Appl. Microbiol., 55: 215-237.

Shiklomonov, I.A. (2000). Appraisal and Assessment of world water Resources. Water International, 25(1): 11-32.

Tebbutt, T.H.Y. (1998). Principles of water quality control. $5^{\text {th }}$ edition. PP.1-45.

Warcup, J.H. (1950). The Soil plate method for isolation of fungi from soil. Nature, Lond., 178: 1477.

Wong, A. and Whetzel, H.H. (1998). Role of fungi in fresh water ecosystem. Biodiversity conserve, Vol. 7:1187-1206. 
Table 1. Fungi isolated from different springs of Samahni valley by Direct Plate Method

\begin{tabular}{|c|l|c|c|c|c|c|c|c|c|c|}
\hline \multirow{2}{*}{$\begin{array}{l}\text { S/ } \\
\text { No }\end{array}$} & \multicolumn{2}{|c|}{ Fungal Species } & \multicolumn{6}{|c|}{ Names of different sampling sites and occurrence of fungi } & \\
\cline { 3 - 12 } & $\begin{array}{l}\text { Nih } \\
\text { ala }\end{array}$ & Kass & Parshala & $\begin{array}{l}\text { Chitti } \\
\text { bawli }\end{array}$ & $\begin{array}{l}\text { Band } \\
\text { ala }\end{array}$ & $\begin{array}{l}\text { Kho } \\
\text { pani }\end{array}$ & Tatali & Hill & Total \\
\hline 1. & Aspergillus sp. & - & + & + & - & - & + & + & - & 3 \\
\hline 2 & Actornmucoc an & & & & & & & + & & 1 \\
\hline 3. & Botrytis sp. & + & + & + & - & - & - & - & - & 3 \\
\hline 4. & Cephalosporium sp. & - & - & - & + & - & - & - & - & 1 \\
\hline 5. & Monocellium sp. & - & - & + & - & - & - & - & + & 1 \\
\hline 6. & Penecillium sp. & - & - & + & + & + & - & - & - & 3 \\
\hline 7. & Sepedonium sp. & - & - & - & + & - & - & - & - & 1 \\
\hline 8. & $\begin{array}{l}\text { Tritirachium } \\
\text { dependens }\end{array}$ & - & - & - & - & - & - & + & - & 1 \\
\hline
\end{tabular}

Key: $+\quad=$ Present,$-\quad=$ Absent

Table 2. Fungi isolated from water of different springs of Samahni valley by Baiting Technique

\begin{tabular}{|c|c|c|c|c|c|c|c|c|c|c|}
\hline \multirow{2}{*}{$\begin{array}{c}\mathrm{S} / \mathrm{N} \\
\text { o. }\end{array}$} & \multirow[t]{2}{*}{ Fungal Species } & \multicolumn{8}{|c|}{ Names of different sampling sites and occurrence of fungi } & \multirow{2}{*}{$\begin{array}{l}\text { Total } \\
\text { Spp. }\end{array}$} \\
\hline & & $\begin{array}{c}\text { Nihal } \\
\text { a }\end{array}$ & $\begin{array}{l}\mathrm{Ka} \\
\text { ss }\end{array}$ & Parshala & $\begin{array}{l}\text { Chitti } \\
\text { bawli }\end{array}$ & $\begin{array}{c}\text { Bandal } \\
\mathrm{a}\end{array}$ & $\begin{array}{l}\text { Kho } \\
\text { pani }\end{array}$ & Tatali & $\begin{array}{c}\text { Hil } \\
1\end{array}$ & \\
\hline 1. & $\begin{array}{l}\text { Aphanomyces } \\
\text { keratinophilous }\end{array}$ & - & - & - & - & - & + & - & - & 1 \\
\hline 2. & Asteromyces sp. & - & - & - & - & - & - & + & - & 1 \\
\hline 3. & Aspergillus sp. & - & + & - & - & - & - & - & - & 1 \\
\hline 4. & Brevilegnia sp. & - & - & - & - & - & - & + & - & 1 \\
\hline 5. & Botrytis sp. & + & - & - & - & - & - & - & - & 1 \\
\hline 6. & Cephalosporium sp. & - & - & + & - & - & - & - & - & 1 \\
\hline 7. & Chloridium sp. & - & - & + & - & - & - & - & - & 1 \\
\hline 8. & Curvularia $\mathrm{sp}$. & - & - & - & - & - & - & - & + & 1 \\
\hline 9. & $\begin{array}{l}\text { Cladosporium } \\
\text { cladosprioides }\end{array}$ & - & - & - & + & - & - & - & - & 1 \\
\hline 10. & Monocellium sp. & - & - & - & - & - & - & - & + & 1 \\
\hline 11. & Dreschleria havaiensis & - & - & - & - & - & + & - & - & 1 \\
\hline 12. & Verticillium sp. & - & - & - & - & + & - & - & - & 1 \\
\hline 13. & Verticillium terrestre & + & - & - & - & - & - & - & - & 1 \\
\hline & Total No. of Species & 2 & 1 & 2 & 1 & 1 & 2 & 2 & 2 & 13 \\
\hline
\end{tabular}


Table 3. Total Number of Fungi isolated from different springs of Samahni

\begin{tabular}{|c|c|c|c|c|c|c|c|c|c|c|}
\hline \multirow[t]{2}{*}{ S/No. } & \multirow[t]{2}{*}{ Fungal Species } & \multicolumn{8}{|c|}{ Names of different sampling sites and occurrence of fungi } & \multirow{2}{*}{$\begin{array}{l}\text { Total } \\
\text { spp. }\end{array}$} \\
\hline & & Nihala & Kass & Parshala & $\begin{array}{l}\text { Chitti } \\
\text { bawli }\end{array}$ & Bandala & $\begin{array}{l}\text { Kho } \\
\text { pani }\end{array}$ & Tatali & Hill & \\
\hline 1. & Aspergillus sp. & - & + & - & - & + & + & + & + & 5 \\
\hline 2. & Achlya prolifera & - & - & - & - & - & - & - & + & 1 \\
\hline 3. & $\begin{array}{l}\text { Aphanomyces } \\
\text { keratinophilous }\end{array}$ & - & - & - & - & - & + & - & - & 1 \\
\hline 4. & Asteromyces sp. & - & - & - & - & - & - & + & - & 1 \\
\hline 5. & Botrytis sp. & + & + & - & + & - & - & - & - & 3 \\
\hline 6. & Brevilegnia sp. & - & - & - & - & - & - & + & - & 1 \\
\hline 7. & Cephalosporium sp. & - & - & + & + & + & - & - & + & 4 \\
\hline 8. & Chloridium sp. & & - & + & - & - & - & - & - & 1 \\
\hline 9. & Curvularia sp. & - & - & - & - & - & - & - & + & 1 \\
\hline 10. & $\begin{array}{l}\text { Cladosporium } \\
\text { cladosprioides }\end{array}$ & - & - & - & + & - & - & - & - & 1 \\
\hline 11. & $\begin{array}{l}\text { Dreschleria } \\
\text { havaiensis }\end{array}$ & - & - & - & - & - & + & - & - & 1 \\
\hline 12. & Fusarium sp. & - & - & + & - & - & - & + & - & 2 \\
\hline 13. & Monocellium sp. & - & - & - & - & - & - & - & + & 1 \\
\hline 14. & Mycogone nigra & - & - & + & - & - & - & - & - & 1 \\
\hline 15. & Nigrospora oryzae & - & - & + & - & - & - & - & - & 1 \\
\hline 16. & Penicillium sp. & - & - & + & + & + & - & - & - & 3 \\
\hline 17. & Saprolegnia sp. & - & - & - & - & - & + & - & - & 1 \\
\hline 18. & Sepedonium sp. & - & - & - & + & - & - & - & - & 1 \\
\hline 19. & $\begin{array}{l}\text { Tritirachium } \\
\text { dependens }\end{array}$ & - & - & - & - & - & - & + & - & 1 \\
\hline 20. & Verticillium sp. & - & - & - & - & + & - & - & - & 1 \\
\hline 21. & Verticillium terrestre & + & - & - & - & - & - & - & - & 1 \\
\hline \multicolumn{2}{|c|}{ Total No. of Species } & 2 & 2 & 6 & 5 & 4 & 4 & 5 & 5 & 33 \\
\hline
\end{tabular}


Table 4. The temperature and $\mathrm{pH}$ of sampled spring water

\begin{tabular}{|c|c|c|c|c|}
\hline \multirow{2}{*}{ S/No. } & \multirow{2}{*}{ Spring's name } & \multicolumn{2}{|c|}{ Temperature } & \multirow{2}{*}{$\mathrm{pH}$} \\
\cline { 3 - 4 } & & Atm. Temp. & Water Temp. & \\
\hline 1. & Nihala & $32^{\circ} \mathrm{C}$ & $18^{\circ} \mathrm{C}$ & 6.0 \\
\hline 2. & Kass & $32^{\circ} \mathrm{C}$ & $20^{\circ} \mathrm{C}$ & 6.5 \\
\hline 3. & Parshala & $35^{\circ} \mathrm{C}$ & $31^{\circ} \mathrm{C}$ & 6.1 \\
\hline 4. & Chitti bawli & $36^{\circ} \mathrm{C}$ & $25^{\circ} \mathrm{C}$ & 7.5 \\
\hline 5. & Bandala & $29^{\circ} \mathrm{C}$ & $27^{\circ} \mathrm{C}$ & 6.5 \\
\hline 6. & Kho pani & $29^{\circ} \mathrm{C}$ & $23^{\circ} \mathrm{C}$ & 6.7 \\
\hline 7. & Tatali & $28^{\circ} \mathrm{C}$ & $20^{\circ} \mathrm{C}$ & 5.9 \\
\hline 8. & Hill & $26^{\circ} \mathrm{C}$ & $19^{\circ} \mathrm{C}$ & 5.5 \\
\hline
\end{tabular}
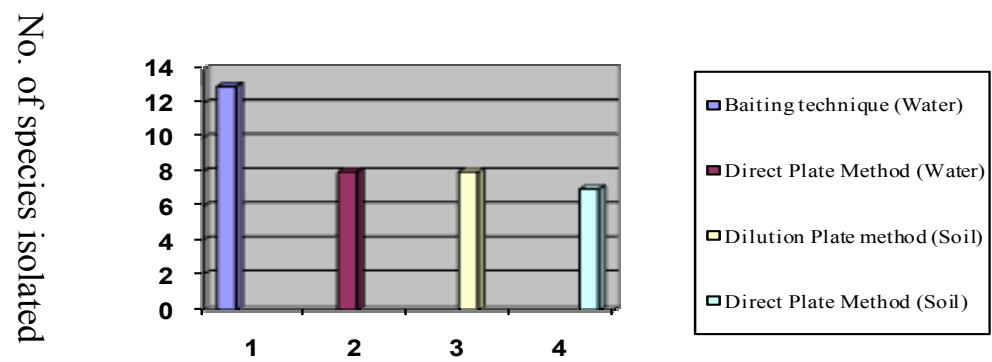

Figure 1. Total No. of fungal species isolated by different methods from different springs of valley Samahni
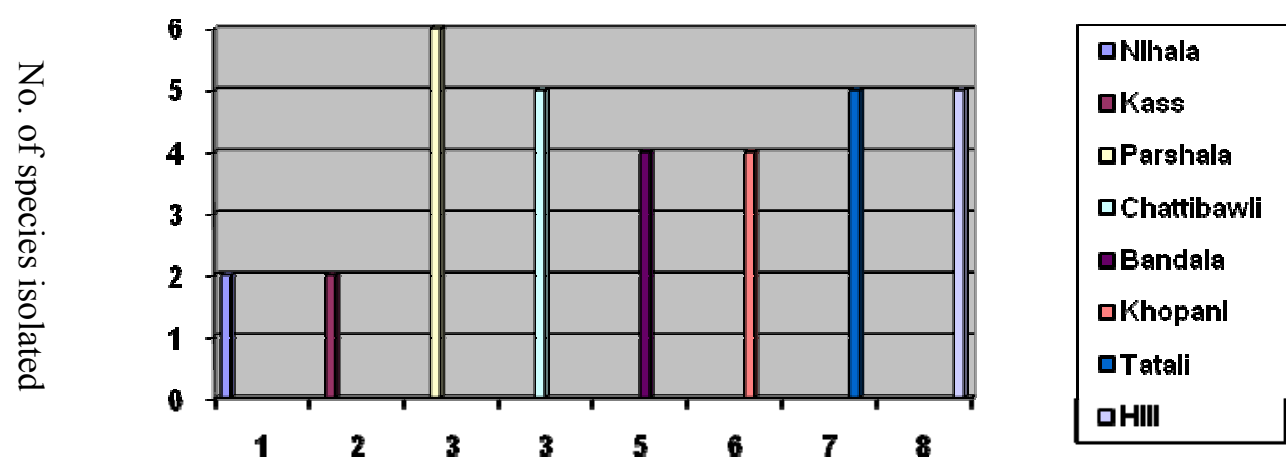

Figure 2. Total number of fungal species recorded from different springs of valley Samahni 


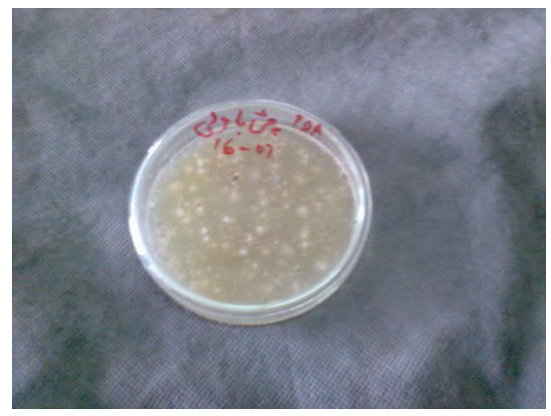

Figure 3. Fungus: Cephalosporium sp growing on PDA

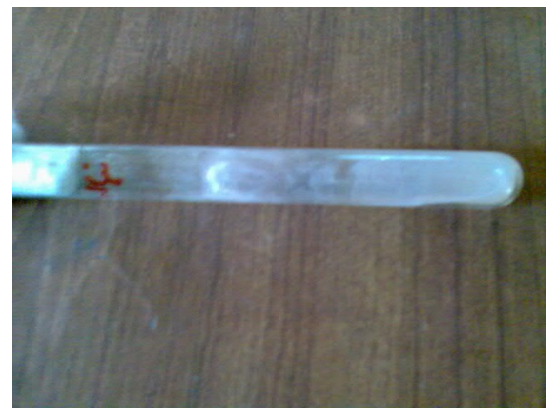

Figure 4. Fungus: Verticillium terrestre growing on PDA

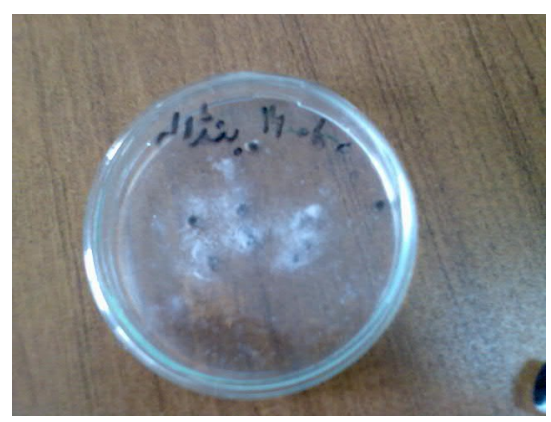

Figure 5. Fungus: Aspergillus sp. growing on PDA

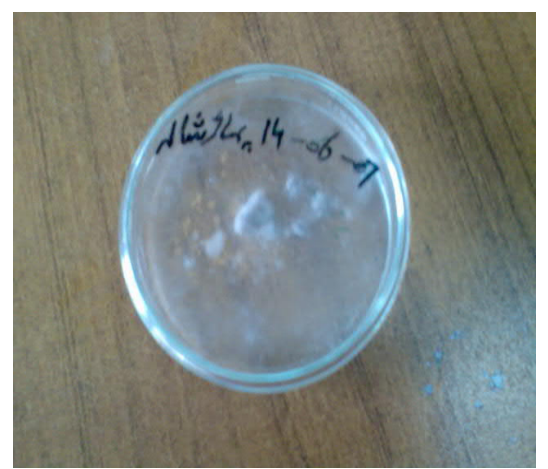

Figure 6. Fungus: Mycogone nigra growing on PDA 